\title{
Ertugliflozin - inhibitor SGLT2
}

\author{
MUDr. Eva Račická
}

Diabetologická a interní ambulance Ostrava

Inhibitory sodíko-glukózových kotransportérů (SGLTi) jsou důležitou nejnovější terapeutickou strategií v léčbě diabetes mellitus 2. typu. Ertugliflozin je nový vysoce selektivní a reverzibilní inhibitor sodík-glukózového transportéru 2 (SGLT2). Tento transportér je zodpovědný za renální reabsorpci glukózy. Tímto mechanismem ertugliflozin zvýší exkreci glukózy ledvinami, což vede k poklesu glykemie a zlepšení kompenzace diabetu bez rizika hypoglykemie. Jde o mechanismus účinku nezávislý na působení inzulinu.Ertugliflozin byl schválen Evropskou Medicínskou agenturou (EMA) pro léčbu diabetes mellitus typ 2 v Evropě v březnu 2018. Je schválen pro použití v monoterapii a jako přídatná léčba k dalším antidiabetikům. V článku je shrnutí poznatků o mechanismu působení, klinické účinnosti a bezpečnosti léku.

Klíčová slova: inhibice SGLT12, diabetes mellitus 2. typu, ertugliflozin, kompenzace diabetu.

\section{Ertugliflozin - SGLT2 inhibitor}

Sodium-glucose transporter 2 inhibitors (SGLT2i) are the most recent therapeutic strategy in the treatment of type2 diabetes mellitus. Ertugliflozin is the new highly selective and reversible SGLT2inhibitor. This cotransporter is responsible for renal reabsorpction of glucose. Due to this mechanism ertugliflozin increases glucose excretion by the kidney, resulting in reduced glycaemia and improved diabetes control with very low risk of hypoglycaemia. This mechanis of action is completely independent of the action of insulin. Ertugliflozin has been aproved by EMA for treatment od diabetes mellitus type 2 in March 2018. Ertugliflozin is aproved for monotherapy and as add-on therapy to oral antidiabetic agents. In this article there is a summary of knowledge about mechanism of action, efficacy and safety of ertugliflozin.

Key words: SGLT2 inhibition, diabetes mellitus typ 2, ertugliflozin, glycemic control.

\section{Úvod}

Diabetes mellitus 2. typu (DM2T) je nejčastější metabolickou chorobou vyznačující se v počátku onemocnění relativním nedostatkem inzulinu, který vede v organismu k nedostatečnému využití glukózy projevujícímu se hyperglykemií. Porucha má progredující charakter. Diabetes mellitus 2. typu vzniká při kombinaci porušené sekrece inzulinu a jeho působení v cílových tkáních, přičemž kvantitativní podíl obou poruch může být rozdílný. Nezbytným předpokladem vzniku diabetu 2. typu je prítomnost obou poruch, na nichž se podílejí jak faktory genetické, tak i faktory zevního prostředí. V léčbě diabetes mellitus 2. typu (DM2T) nastal v posledních letech velký pokrok, do léčby byla zařazena nová antidiabetika. Účinek farmakologických intervencí je vázán jednak na př́tomnost inzulinu, či jeho účinek, ale léky ze skupiny gliflozinů, tedy inhibitory SGLT2, jsou skupinou léků, které snižují glykemii naprosto nezávisle na inzulinu. Etiopatogeneze DM2T vždy zahrnuje kombinaci inzulinové rezistence a poruchy sekrece inzulinu, která v průběhu nemoci se $s$ delším trváním prohlubuje. Proto je potřebné, aby k dosažení dlouhodobé uspokojivé kompenzace byla použita kombinace léků s různým mechanismem působení. Vedle samotné hyperglykemie je také u pacientů s DM2T) nutno léčit přidružená onemocnění, která se velmi často u pacientů vyskytují - hypertenze, dyslipidemie, obezita a řada dalších. Požadavky na současná moderní antidiabetika obsahují nejen požadavek na úpravu hyperglykemie, ale také aby príznivě ovlivňovala přidružená onemocnění, která jsou spojená s rizikem kardiovaskulárních onemocnění (1).

Úloha ledvin v udržování glukózové homeostázy je dobře známá. Glukóza je v glomerulech filtrována, ale v proximálním tubulu se kompletně resorbuje zpět. Je-li glykemie zvýšená a dojde-li k překročení tzv. renálního prahu, pak se glukóza dostává do moči a vzniká glykosurie. V 90. letech bylo zjištěno, jaký mechanismus je zodpovědný za zpětnou resorpci glukózy. V epiteliálních buňkách se nalézají dva typy glukózových kotransportérů SGLT.SGLT1 je exprimován primárně v tenkém střevu a v S3 segmentu proximálního renálního tubulu a v myokardu a SGLT2 se zřej- 


\section{FARMAKOLOGICKÝ PROFIL}

ERTUGLIFLOZIN - INHIBITOR SGLT2

mě nacházejí pouze v proximálním tubulu v S1 a S2 segmentu ledviny (2). Oba transportní systémy mají definovanou (individuálně) maximální kapacitu, po jejímž vysycení se nestačí veškerá glukóza vstřebat a vyvine se glykosurie. SGLT2 je odpovědno za 80-90 \% renální reabsorpce glukózy a SGLT1 za zbývajících 10-20 \%. Údaje ze zvî́recích modelů diabetu a z preklinických lidských studií svědčí o tom, že hyperglykemie u DM2T je spojená se signifikantně zvýšenou expresí SGLT2 a GLUT 2 proteinů (3). V současné době jsou v klinické praxi používány ze skupiny gliflozinů canagliflozin dapagliflozin, a empagliflozin. Tyto léky se staly úspěšnými léky pro léčbu DM2T. Nyní po schválení v roce 2018 k nim přibyl ertugliflozin.

\section{Mechanismus účinku}

SGLT2 je hlavním transportérem odpovědným za reabsorpci glukózy z glomerulárního filtrátu zpět do oběhu. Ertugliflozin je silným, selektivním a reverzibilním inhibitorem SGLT2. Inhibicí SGLT2 ertugliflozin snižuje renální reabsorpci filtrované glukózy a snižuje renální práh glukózy a tím zvyšuje vylučování glukózy

Tab. 1. In vitro účinnost a selektivita různých inhibitorů SGLT2

\begin{tabular}{|l|c|c|c|}
\hline Sloučenina & SGLT2IC $_{\mathbf{5 0}}, \mathbf{n m o l} / \mathbf{I}$ & SGLT1IC $_{\mathbf{5 0}}, \mathbf{n m o l} / \mathbf{I}$ & Selektivita SGLT2/SGLT1 $^{\text {S }}$ \\
\hline Empagliflozin $^{1,2}$ & 3,1 & 8,300 & 2,700 \\
\hline Ertugliflozin $^{1,3}$ & 0,9 & 1,960 & 2,200 \\
\hline Dapagliflozin $^{1,2}$ & 1,2 & 1,400 & 1,200 \\
\hline Canagliflozin $^{1,4}$ & 4,2 & 663 & 160 \\
\hline Sotagliflozin $^{5}$ & 1,8 & 36 & 20 \\
\hline
\end{tabular}

Prevzato se souhlasem Mudaliar S et al.1

SGLT = transportér společný pro sodík a glukózu; IC50 = polovina maximální inhibiční koncentrace.

1. Mudaliar S et al. Diabetes Care. 2015; 38: 2344-2353. Grempler R et al. Diabetes Obes Metab. 2012; 14: 83-90.

3. Mascitti V et al. J Med Chem. 2011; 54: 2952-2960. ${ }^{4}$ Kuriyama C et al. J Pharmacol Exp Ther. 2014; 351: 423-431.

5.Zambrowicz B et al. Clin Pharmacol Ther. 2012; 92: 158-169.

do moči. Ertugliflozin (vzorec: $\mathrm{C} 22 \mathrm{H} 25 \mathrm{ClO}$ ) je vysoce selektivní in vitro (> 2000x) pro SGLT2 receptory než pro SGLT1 (4) (Graf 1).

\section{Farmakokinetika, metabolismus, exkrece}

$\checkmark$ otevřené studii fáze 1 se prokázalo, že ertugliflozin dosahuje vrcholové plazmatické koncentrace asi za 1 hodinu po podání jedné dávky 25 mg per os u zdravých osob, což indikuje rychlou absorpci per os. Systémová expozice byla proporcionální dávce v rozsahu 0,5-300 mg, zatímco poločas eliminace byl kolem 17 hodin, což umožňuje podání
1× denně. Při podávání ertugliflozinu jednou denně se rovnovážného stavu dosáhne po 4 až 6 dnech (5).

Ertugliflozin je vázán na plazmatické proteiny (96\% u krys a psů, $94 \%$ u lidí). Ertugliflozin je z 93,6 \% vázán na plazmatické proteiny, a to nezávisle na plazmatických koncentracích ertugliflozinu. Míra vazby na plazmatické proteiny není u pacientů s poruchou funkce ledvin nebo jater významně změněna (6).

\section{Biotransformace}

Primárním mechanismem odstraňování ertugliflozinu je metabolizace. Hlavní metabolickou ces-

Graf 1. VERTIS MONO: Design studie ${ }^{1,2}$

Dospělí ve věku $\geq 18$ let s T2DM nedostatečně kontrolovaným pomocí diety a pohybu
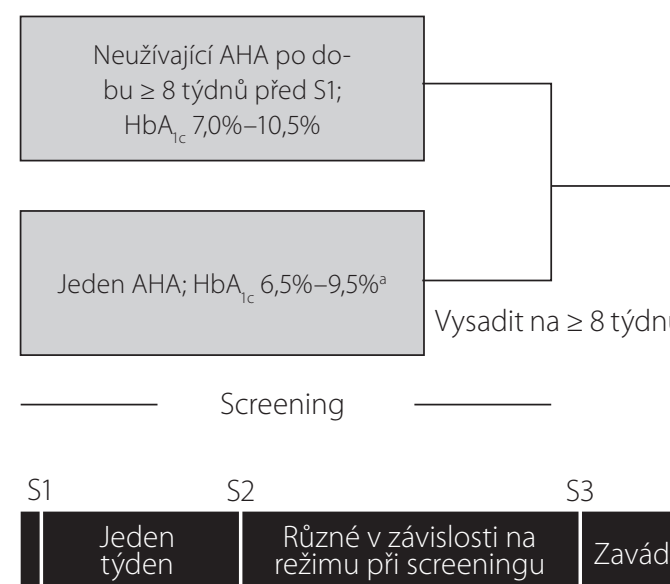

Týden
S2

\section{Různé v závislosti na režimu při screeningu}

S3

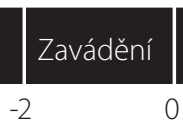

Placebo ve fázi $A(n=153)$

Přechod na metformin ve fázi
ERTU 5 mg $1 \times$ denně $(n=156)$

ERTU 15 mg $1 \times$ denně $(n=152)$

Doba užívání

Poradenství/monitoring ohledně dietního a pohybového režimu

aPacienti v této skupině byli randomizováni, pouze pokud byla při návštěvě S3 zjištěna hodnota HbA 7,0 \%-10,5\% (včetně).

${ }^{\circ}$ Metformin byl určen pouze pro pacienty, kteři ve fázi A nedostali glykemický záchranný lék.

‘Glykemický záchranný lék (metformin ve fázi A / glimepirid ve fázi B) byl podán pacientům, kteřív průběhu testu dosáhli postupně se zpřísňujíci glykemické prahové hodnoty.

T2DM = diabetes mellitus 2. typu; $A H A=$ antihyperglykemický prípravek; $R=$ randomizace; $E R T U=$ ertugliflozin.

1. Terra SG et al. Diabetes Obes Metab. 2017; 19: 721-728. 2. Aronson Ret al. Diabetes Obes Metab. 2018. [Epub ahead of print]

Sběr dat pro primární cílový ukazatel: změna oproti výchoz hodnotě $\mathrm{HbA}_{1 c}$ 
FARMAKOLOGICKÝ PROFIL 【

ERTUGLIFLOZIN - INHIBITOR SGLT2

tou ertugliflozinu je O-glukuronidace na dva glukuronidy zprostředkovaná UGT1A9 a UGT2B7. Tyto dva glukuronidy jsou v klinicky relevantních koncentracích farmakologicky inaktivní. Metabolizace ertugliflozinu zprostředkovaná CYP cytochromem P450 (oxidativní) je minimální (12\%).

\section{Eliminace}

Střední hodnota systémové plazmatické clearance po intravenózní dávce $100 \mu \mathrm{g}$ byla 11 I/hod. Střední hodnota eliminačního poločasu u pacientů s diabetes typu 2 s normální funkcí ledvin byla na základě populační farmakokinetické analýzy odhadnuta na 17 hodin. Po perorálním podání roztoku [14C]-ertugliflozinu zdravým subjektům bylo přibližně 41 \% radioaktivity související s léčivem eliminováno do stolice a $50 \%$ do moči. Pouze 1,5\% podané dávky bylo vyloučeno jako nezměněný ertugliflozin do moči a 34 \% jako nezměněný ertugliflozin do stolice, což je pravděpodobně důsledkem vylučování glukuronidových metabolitů do žluče a následné hydrolýzy na mateřskou látku (7).

Podání ertugliflozinu s vysoce tučným a vysokokalorickým jídlem v porovnání se stavem nalačno snižuje $C_{\max }$ ertugliflozinu o 29 \% a prodlužuje $T_{\max }$ ertugliflozinu o 1 hodinu, nicméně AUC nemění.

Pozorovaný vliv potravy na farmakokinetiku ertugliflozinu se nepovažuje za klinicky relevantní a ertugliflozin Ize podávat s jídlem nebo bez jídla. V klinických hodnoceních fáze 3 se ertugliflozin podával bez ohledu na jídlo (8).

\section{Interakce}

\section{In vitro hodnocení ertugliflozinu}

Ertugliflozin a glukuronidy ertugliflozinu v in vitro studiích neinhibovaly, ani neinaktivovaly CYP 1A2, 2C9, 2C19, 2C8, 2B6, 2D6 nebo 3A4 a neindukovaly CYP 1A2, 2B6 nebo 3A4.

Ertugliflozin a glukuronidy ertugliflozinu in vitro neinhibovaly aktivitu UGT 1A6, 1A9 nebo 2B7.

Ertugliflozin byl in vitro prì vyšších koncentracích, které nejsou klinicky relevantní, slabý inhibitor UGT 1A1 a 1A4. Glukuronidy ertugliflozinu na tyto izoformy neměly žádný vliv. Celkově je nepravděpodobné, že by ertugliflozin měl vliv na farmakokinetiku současně podávaných léčivých prípravků eliminovaných těmito enzymy.

Ertugliflozin nebo glukuronidy ertugliflozinu in vitro ve významné míre neinhibují P-gp,

Graf 2. VERTIS MONO: Snižení tělesné hmotnosti a systolického krevního tlaku ve 26. týdnu',2

Sekundární cílové ukazatele, populace celého analytického souboru ${ }^{\mathrm{a}, \mathrm{b}}$

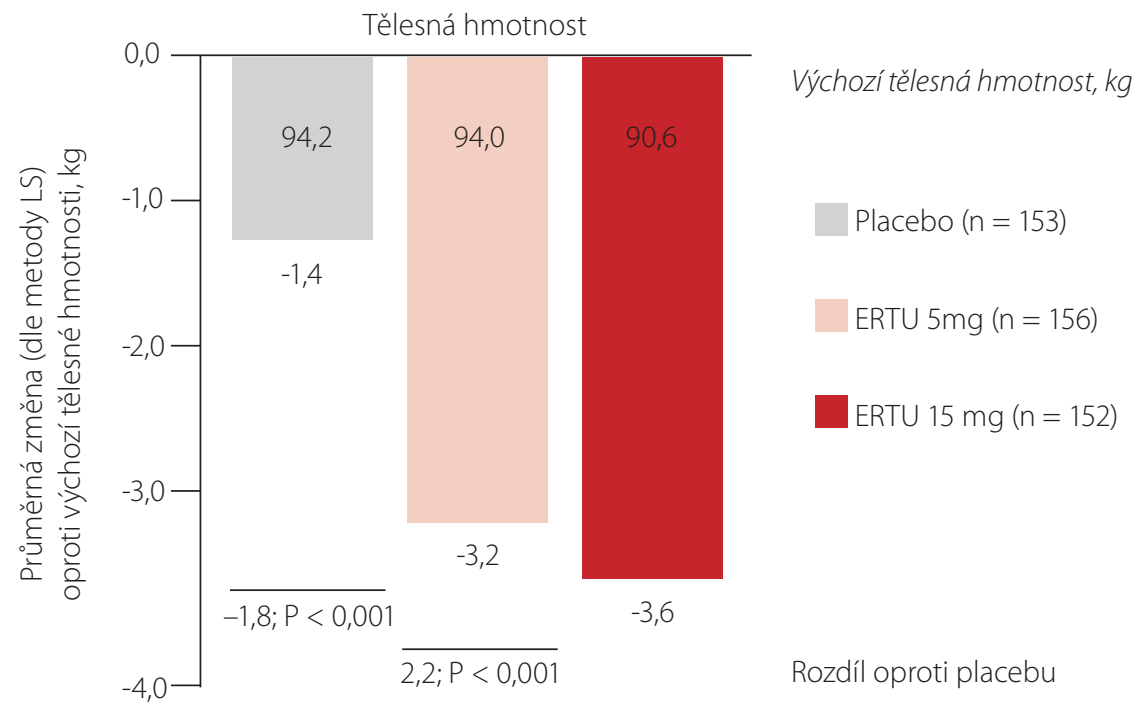

Systolický krevní tlak

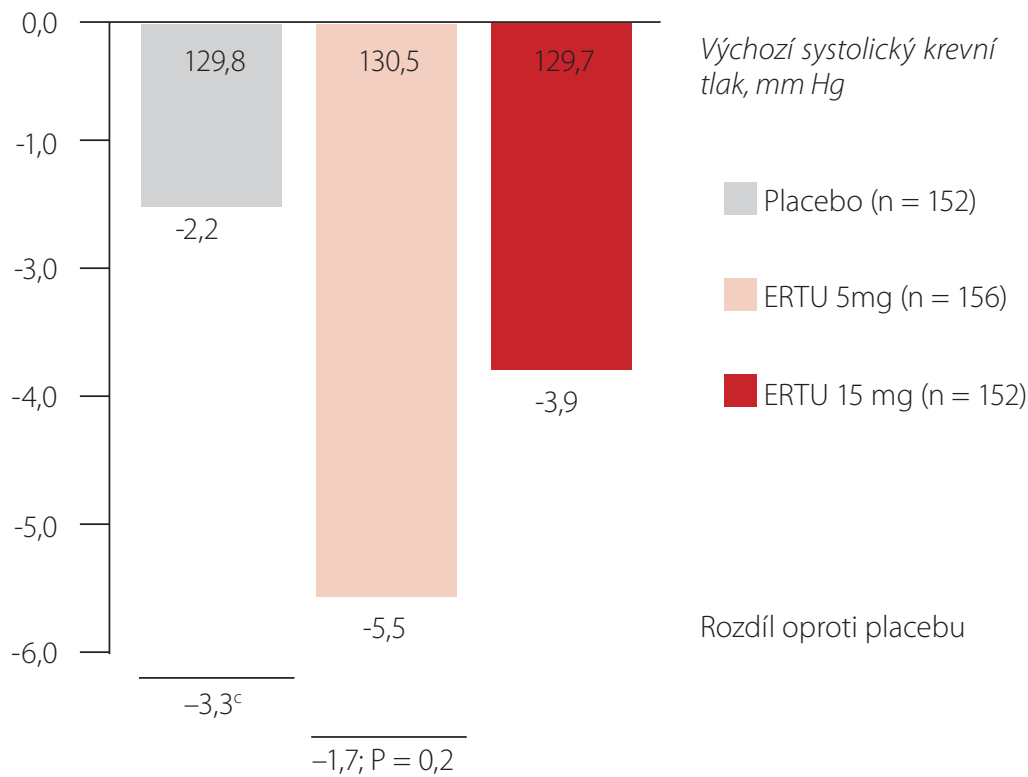

Ertugliflozin není indikován pro snižování tělesné hmotnosti nebo systolického krevního tlaku. a Sledovaná populace zahrnuje všechny randomizované pacienty, kteři dostali alespoň 1 dávku studovaného léku a podstoupili alespoň 1 měrení proměnné veličiny analýzy (výchozí nebo pozdější).

' SStředni hodnoty získané metodou LS, očištěné od vivu léčby, času, předchoziho antihyperglykemického prípravku, výchozí eGFR a interakce čas-léčba.

c $P$ - hodnota netestována; predem specifikované nařizené testovací pořadí zastaveno. $L S=$ nejmenší čtverce; ERTU = ertugliflozin; eGFR = odhadovaná glomerulární filtrace. 1.Terra SG et al. Diabetes Obes Metab. 2017; 19: 721-728. ².Data on file, MSD.

transportéry OCT2, OAT1 nebo OAT3, transportní polypeptidy OATP1B1 a OATP1B3 při klinicky významných koncentracích. Celkově je nepravděpodobné, že by ertugliflozin měl vliv na farmakokinetiku současně podávaných léčivých prípravků, které jsou substráty těchto transportérů (8).

S ohledem na nástup fixních kombinací byla provedena studie s fixní kombinací ertugliflozin- -sitagliptin. Tato otevřená randomizovaná, s jednou dávkou vedená ve třech periodách cestou cross-over (překř́žení) studie u 12 zdravých dospělých byla provedená s podáním 15 mg ertugliflozinu, 100 mg sitaglitpinu a ertugliflozin +sitaglipin. Studie prokázala, že současné podání ertugliflozinu a sitagliptinu nemělo žádný efekt ani na ertugliflozin $A U C_{\text {inf }}$ nebo $C_{\text {max }}$; obdobně ertugliflozin neovlivnil u sitagliptinu $A_{U} C_{\text {inf }}$ nebo 


\section{FARMAKOLOGICKÝ PROFIL}

ERTUGLIFLOZIN - INHIBITOR SGLT2

Graf 3. VERTIS MONO: SniženíHbA, ve 26. týdnu'

Primární cílový ukazatel, populace celého analytického souborua,b
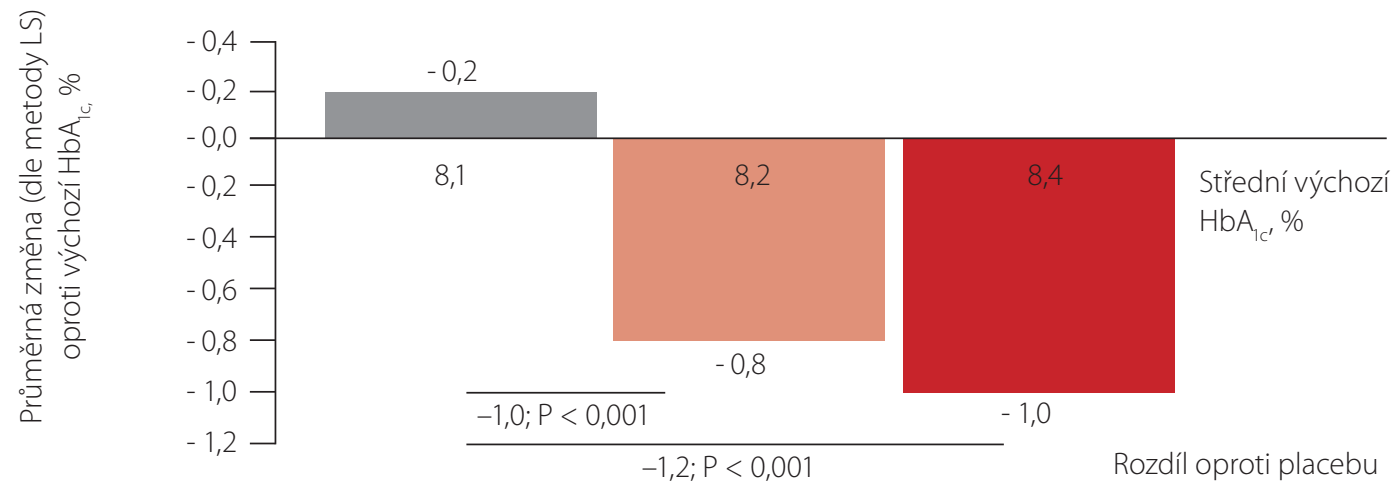

Placebo $(n=153)$

ERTU $5 \mathrm{mg}(\mathrm{n}=156)$

ERTU $15 \mathrm{mg}(\mathrm{n}=151)$
$C_{\text {max }}$. Obdobné výsledky byly získány s metforminem. Absence farmakokinetických interakcí demonstruje, že ertugliflozin může být současně podán jak se sitagliptinem, tak s metforminem bez úpravy dávky (9).

Protože selhání ledvin je obvyklou komorbiditou u DM2T, bylo také provedeno vyhodnocení farmakokinetiky a farmakodynamiky prì renálním poškození. Jedna per os podaná dávka $15 \mathrm{mg}$ ertugliflozinu byla podaná zdravým subjektům a subjektům s různým stupněm renálního poškození. Dle očekávání byla systémová expozice k ertugliflozinu zvýšená asi < 2násobně u osob s renálním poškozením ve srovnání k osobám se zachovanou renální funkcí. 24hodinová močová exkrece glukózy klesala s klesající renální funkcí vzhledem ke snižené filtraci glukózy Ertugliflozin je proto dobře tolerován u osob s normální renální funkcía u osob s DM2T s renálním poškozením (10).

Současné podávání simvastatinu a ertugliflozinu vedlo ke 24\% zvýšení AUC a k 19\% zvýšení C $C_{\max }$ Simvastatinu a k 30\% zvýšení AUC a k 16\% zvýšení $C_{\max }$ kyseliny simvastatinové. Mechanismus mírných zvýšení hladin simvastatinu a kyseliny simvastatinové není známý, přičemž zvýšení není způsobeno inhibicí OATP ertugliflozinem. Tato zvýšení se nepovažují za klinicky významná (8).

\section{Klinická účinnost a bezpečnost}

Účinnost a bezpečnost ertugliflozinu byla hodnocena $\vee 7$ multicentrických, randomizovaných, dvojitě zaslepených, placebem nebo aktivním komparátorem kontrolovaných klinických studiích fáze 3 zahrnujících 4863 pacientů s diabetem typu 2, včetně studie u 468 pacientů se středně závažnou poruchou funkce ledvin. Rasová distribuce byla 76,8 \% běloši, 13,3 \% Asiaté, 5,0 \% černoši a 4,8 \% ostatní. Hispánští nebo latinskoameričtí pacienti představovali $24,2 \%$ populace. Průměrný věk pacientů byl 57,8 let (rozmezí 21 až 87 let), přičemž 25,8 \% pacientů bylo ve věku $\geq 65$ let a $4,5 \% \geq 75$ let (8).

\section{Studie fáze II}

Ertugliflozin byl vyhodnocen v dávkách od $1-25 \mathrm{mg}(1,5,1,20 \mathrm{mg}) 1 \times$ denně u pacientů s DM2T při léčbě s metforminem se stabilní dávkou metforminu, byl srovnáván se sitagliptinem 100 mg a placebem. Průměrný pokles HbA ${ }_{1 c}$ od počátku do týdne 12 byl u všech skupin léčených ertugliflozinem (od -0,45 \% do -0,72\% v závislosti na léčebné skupině ve srovnání s placebem. Konkrétně, dávky více než 5 mg/den měly účinek na $\mathrm{HbA}_{1 c^{\prime}}$ který byl numericky podobný těm, které byly získány léčbou se sitagliptinem 100 mg. Větší část pacientů léčených ertugliflozinem dosáhla $\mathrm{HbA}_{\mathrm{lc}}<7 \%$ v týdnu 12 a došlo k signifikantnímu snížení hladiny glykemie (11).

\section{Studie fáze III}

Studie VERTIS MONO fáze III vyhodnocovala celkem 461 pacientů s diabetem typu 2, kteři nebyli dostatečně kontrolováni dietními opatřeními a tělesnou aktivitou a kteří se zúčastnili randomizované, dvojitě zaslepené, multicentrické, 26týdenní, placebem kontrolované studie k vyhodnocení účinnosti a bezpečnosti ertugliflozinu v monoterapii. Tito pacienti, kteří nedostávali žádnou základní antihyperglykemickou léčbu, byli randomizováni do skupiny léčené 5 mg ertugliflozinu, 15 mg ertugliflozinu nebo placebem podávanými jednou denně. Změna v HbA $A_{1 c}$ od počátku do týdne 26 ukázala signifikantně větší pokles u ertugliflozinu 5 mg, $(-0,99 \% ; p<0,001)$ a 15 mg (-1,16\%; $p<0,001)$ ve srovnání s placebem, což bylo nejvíce evidentní u pacientů s $\mathrm{HbA}_{1 c}>8 \%$. V týdnu 26 ertugli- flozin 5 mg a 15 mg také dosáhly signifikantně větší snížení v sekundárních cílech, jmenovitě v hladině glykemie na lačno (FPG) a 2hodinové postprandiální glykemii (2-hod PPG) ve srovnání s placebem (12) (Graf 2-4).

\section{Ertugliflozin jako přídatná kombinační terapie s metforminem (VERTIS MET)}

Celkem 621 pacientů s diabetes typu 2 nedostatečně kontrolovaných monoterapií metforminem ( $\geq 1500 \mathrm{mg} / \mathrm{den}$ ) se účastnilo randomizované, dvojitě zaslepené, multicentrické, 26týdenní, placebem kontrolované studie, hodnotící účinnost a bezpečnost ertugliflozinu v kombinaci s metforminem.

Pacienti byli randomizováni do skupiny léčené 5 mg ertugliflozinu, 15 mg ertugliflozinu nebo placebem podávanými jednou denně navíc k pokračující základní terapii metforminem ( $\geq 1500$ mg/ den $\geq 8$ týdnů) prì nedostatečné kompenzaci.

V týdnu 26 obě skupiny léčené ertugliflozinem prokázaly signifikantní pokles $\mathrm{HbA}_{1 c}$ a FBG od počátku studie. Speciálně ertugliflozin $5 \mathrm{mg}$ ve srovnání s placebem snízil $\mathrm{HbA}_{1 c} \circ 0,7 \% \mathrm{p}<$ 0,001) a FPG o -1,43 mmol// ( $<<0,001)$, zatímco ertugliflozin 15 mg snížil HbA $\mathrm{H}_{1 c} \circ$ 0,88 \% ( $\mathrm{p}<$ $0,001)$ a FBG o -2,05 mmol/l (p<0,001) (13).

\section{Studie VERTIS FACTORIAL}

Jde o studii ertugliflozinu a sitagliptinu jako př́datné kombinační léčby s metforminem. Celkem 1233 pacientů s DM 2T se účastnilo randomizované, dvojitě zaslepené, multicentrické, 26týdenní, aktivním komparátorem kontrolované studie hodnotící účinnost a bezpečnost 5 mg nebo 15 mg ertugliflozinu v kombinaci se sitagliptinem 100 mg v porovnání s jednotlivými léčivými látkami. Pacienti s DM2T nedostatečně kontrolovaní 

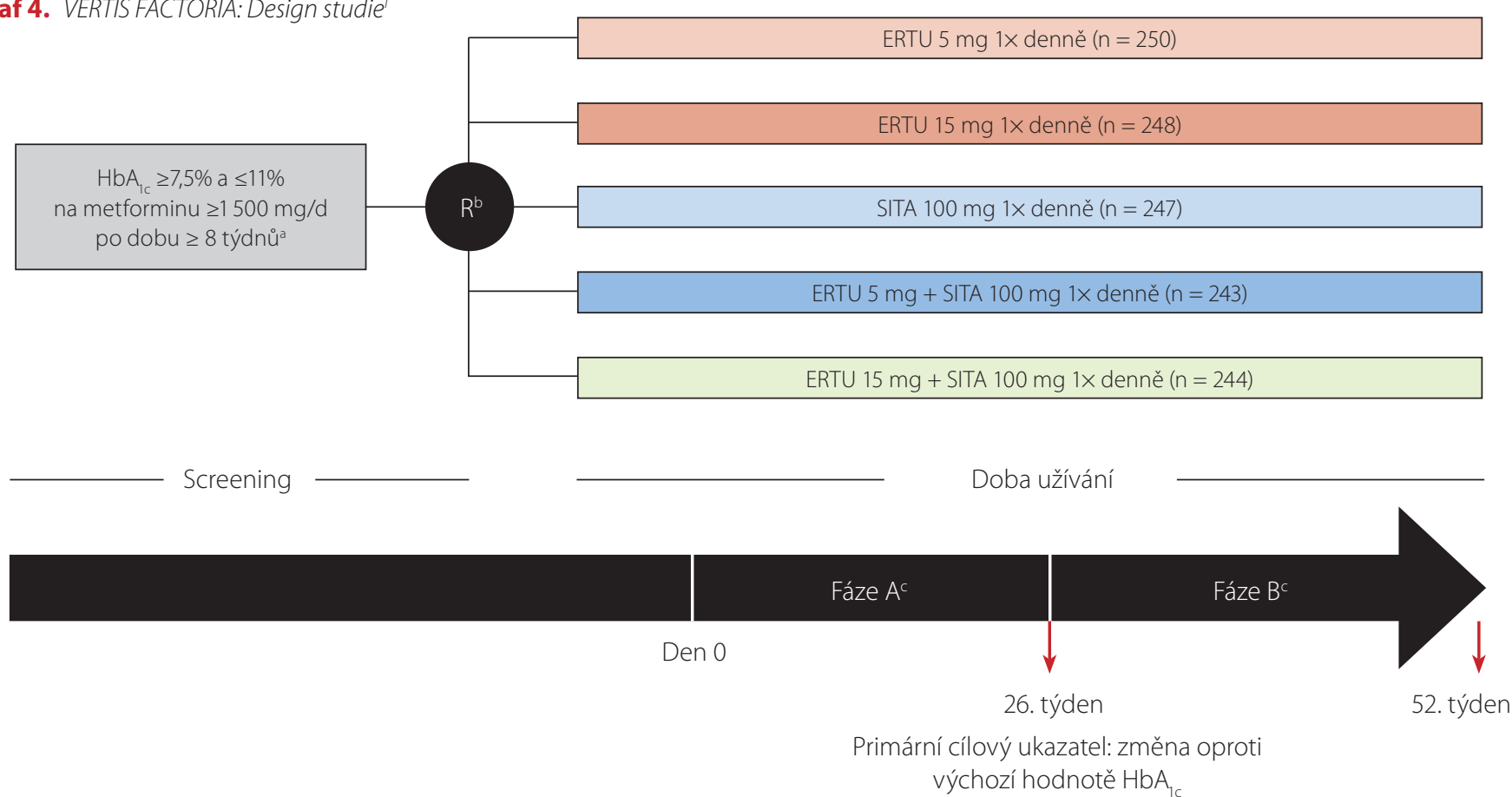

aPacienti, kteřív době screeningu uživali metformin po dobu < 8 týdnů nebo uživali dávku < 1500 mg/d, prošli stabilizačním obdobím, kdy jim byla zvýšena dávka, a po 8 týdnech monoterapie metforminem v dávce $\geq 1500$ mg/den byli zpưsobilí pro účast ve studii.

${ }^{\natural}$ Randomizováno bylo celkem 1233 pacientů, 1 pacient v rameni užívajícím ERTU 15 mg + SITA 100 mg neužíval studovaný lék, což znamená 1232 léčených pacientů.

‘Glykemickýzáchranný lék (otevřeně glimepirid, prípadně inzulin glargin, pokud výzkumný pracovník považoval glimepirid za prípravek nevhodný pro daného pacienta) byl nasazen pacientům, kteří splnili kritéria pro jeho nasazení.

T2DM = diabetes mellitus 2. typu; ERTU = ertugliflozin; SITA = sitagliptin.

1. Pratley RE et al. Diabetes Obes Metab. 2018; 20: 1111-1120.

léčbou metforminem ( $\geq 1500 \mathrm{mg} / \mathrm{den}$ ) byli randomizováni do jednoho z pěti ramen s aktivní léčbou: 5 mg nebo 15 mg ertugliflozinu, sitagliptin $100 \mathrm{mg}$ nebo sitagliptin $100 \mathrm{mg} v$ kombinaci s $5 \mathrm{mg}$ nebo 15 mg ertugliflozinu podávané jednou denně navíc k pokračující základní léčbě metforminem.

Po 26 týdnech současné podávání ertugliflozin + sitagliptin bylo signifikantně účinnější než samotná léčba ve snížení $\mathrm{HbA}_{1 c}$ a FPG a stoupající počet pacientů dosáhnul $\mathrm{HbA}_{1 c}$ $<7 \%$.Ertugliflozin $5 \mathrm{mg}$ a ertugliflozin $15 \mathrm{mg}$ a sitagliptin 100 mg prokázaly snížení $\mathrm{HbA}_{1 c}$ od počátku -1,0 \%, -1,1 \% a -1,1\% v tomto pořadí ( $p$ je nesignifikantní mezi těmito 3 skupinami). Navíc sitagliptin v dávce 100 mg dále determinoval další pokles $\mathrm{HbA}_{1 c}$ (ertugliflozin $5 \mathrm{mg}+$ sitagliptin 100 mg -1,5\%; ertugliflozin 15 mg + sitagliptin 100 mg -1,5\%; p<0,004). Obdobné výsledky byly získány pro hodnoty FPG ve snížení od počátku studie. Také větší části pacientů dosáhne HbA1c $<7 \%$ (ertugliflozin 5 mg + sitagliptin 100 mg: 52,3\%; ertugliflozin 15 mg + sitagliptin 100 mg: 49,2\%; ertugliflozin 5 mg: 26,4 \%; ertugliflozin 15 mg: 31, $9 \%$; sitagliptin 100 mg: 32,8 \%) (14). Léčba pak pokračovala další extenzí dvojitě zaslepenou studií 26 týdnů
(15), přičemž efekt ertugliflozinu a sitagliptinu (jako jednotlivé léky nebo při současném podání na úpravu kompenzace se udržel po dobu celkem 52 týdnů. Graf 5-7.

\section{Ertugliflozin jako přídatná kombinační léčba s metforminem a sitagliptinem (VERTIS SITA 2)}

Celkem 463 pacientů s diabetes typu 2 nedostatečně kontrolovaných metforminem ( $\geq 1500 \mathrm{mg} / \mathrm{den}$ ) a sitagliptinem $100 \mathrm{mg}$ jednou denně se účastnilo randomizované, dvojitě zaslepené, multicentrické, 26týdenní, placebem kontrolované studie hodnotíci účinnost a bezpečnost ertugliflozinu. Pacienti byli randomizováni do skupin léčených 5 mg ertugliflozinu, 15 mg ertugliflozinu nebo placebem podávanými jednou denně navíc k pokračující základní léčbě metforminem a sitagliptinem (16). Tato studie sledovala přidání ertugliflozinu 5 nebo 15 mg ve srovnání s placebem k duální kombinaci metformin a sitagliptin po 26 týdnech léčby. Úprava glykemie po 26 týdnech léčby byla více účinná s léčbou ertugliflozinem 5 mg a 15 mg ve srovnání s placebem, konkrétně. průměrná změna $\mathrm{HbA}_{1 c}$ byla větší pro ertugliflo- zin $5 \mathrm{mg}(-0,68 \%, \mathrm{p}<0,001)$ and $15 \mathrm{mg}(-0,76 \%$ $<0,001)$ ve srovnání s placebem $(-0,1 \%)$. Stejný efekt měla léčba na FPG a větší část subjektů léčených ertugliflozinem 5 mg a 25 mg dosáhla cílové hodny $\mathrm{HbA}_{\mathrm{lc}}<7,0 \%$. Extenze studie na 52 týdnů prokázala podobné výsledky (17).

\section{Kombinační léčba ertugliflozinem a sitagliptinem (VERTIS SITA)}

Celkem 291 pacientů s diabetes typu 2 nedostatečně kontrolovaných dietními opatřeními a tělesnou aktivitou se účastnilo randomizované, dvojitě zaslepené, multicentrické, placebem kontrolované, 26týdenní studie k vyhodnocení účinnosti a bezpečnosti ertugliflozinu v kombinaci se sitagliptinem.

Tito pacienti, kteří nedostávali žádnou základní antihyperglykemickou léčbu, byli randomizováni do skupin léčených jednou denně 5 mg ertugliflozinu nebo 15 mg ertugliflozinu $\checkmark$ kombinaci se sitagliptinem (100 mg) nebo do skupiny léčené placebem.

Účastníci studie byli randomizováni $1: 1: 1$ k léčbě ertugliflozin 5 mg + sitagliptin 100 mg, ertugliflozin 15 mg + sitagliptin 100 mg nebo 
Graf 5. VERTIS FACTORIA: Snižení HbA, ve 26. týdnu'

Primární cílový ukazatel, populace celého analytického souborua,b

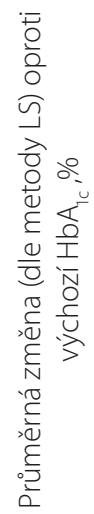

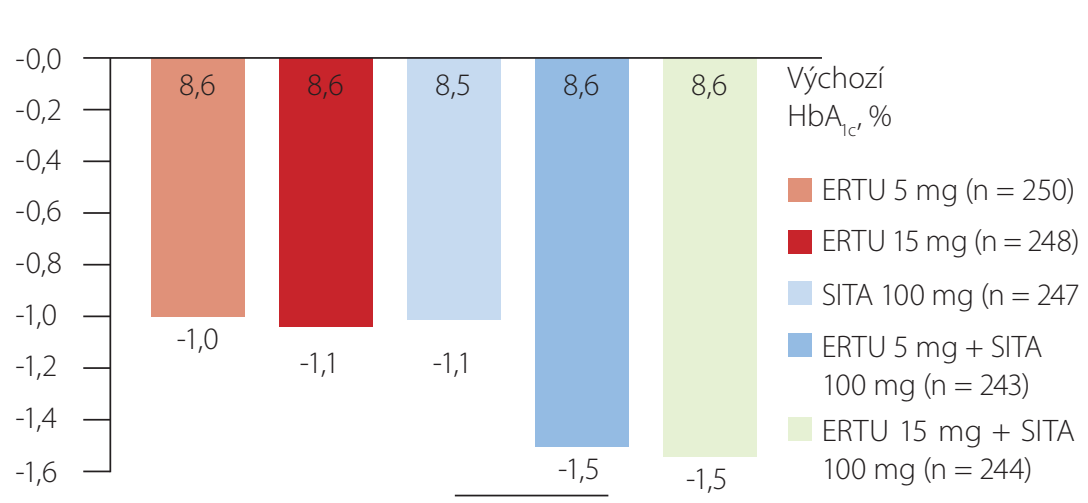

$$
\frac{\frac{-0,4 ; P<0,001}{-0,5 ; P<0,001}}{-0,5 ; P<0,001}
$$

a Sledovaná populace zahrnuje všechny randomizovanéléčené pacienty, kteřípodstoupili alespoň 1 měření proměnné veličiny výsledné účinnosti.

'Data vycházejí z modelu analýzy omezených longitudinálních dat s fixními účinky prì léčbě, výchozí eGFR, časem a interakcí čas-léčba. Chybějicí data byla v modelu rešena implicitně.

$L S=$ nejmenší čtverce; ERTU = ertugliflozin; SITA = sitagliptin; GFR = odhadovaná glomerulární filtrace. 1. Pratley RE et al. Diabetes Obes Metab. 2018; 20: 1111-1120.

Graf 6. VERTIS FACTORIAL: Sniženi tělesné hmotnostive 26. týdnu'

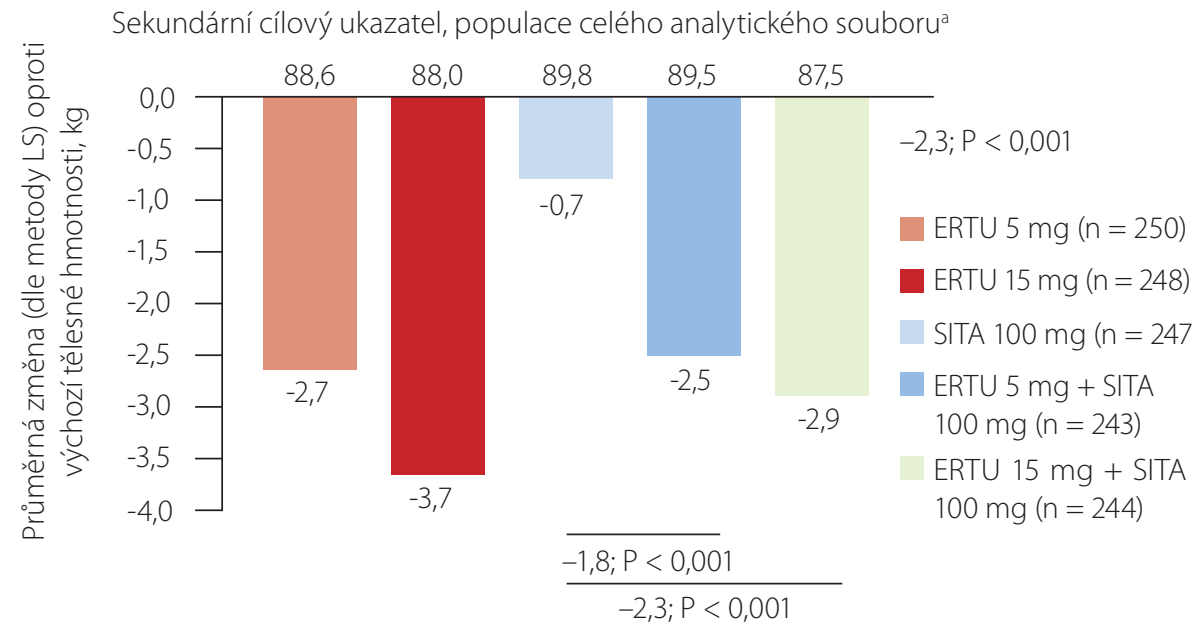

Ertugliflozin není indikován pro redukci tělesné hmotnosti.

a Sledovaná populace zahrnuje všechny randomizované léčené pacienty, kteř́ podstoupili alespoň 1 měreni proměnné veličiny výsledku (výchozí nebo pozdější).

LS = nejmenši čtverce; ERTU = ertugliflozin; SITA = sitagliptin

1. Pratley RE et al. Diabetes Obes Metab. 2018; 20: 1111-1120.

placebo. Dle očekávání po 26 týdnech obě léčené skupiny prokázaly větší snížení $\mathrm{HbA}_{{ }_{1 c^{\prime}}}$ které bylo signifikantní při spárovaném srovnání s placebem (ertugliflozin 5 mg + sitagliptin $100 \mathrm{mg}-1,16 \%$, p < 0,001; ertugliflozin 15 mg + sitagliptin $100 \mathrm{mg}-1,24 \%, p<0,001$ ). Došlo také k významné redukci FPG a 2 hodinové PPG. Jednotlivá srovnání s placebem pro FPG a 2hod PPG byla signifikantní pro FPG a 2hod PPG ( $p<0,001)$. Procento osob, které dosáhly $\mathrm{HbA}_{1 c}$ pod $7 \%$ bylo také vyšší při kombinované léčbě ve srovnání s placebem (ertugliflozin 5 mg + sitagliptin 100 mg: 35,7\%; ertugliflozin $15 \mathrm{mg}+$ sitagliptin $100 \mathrm{mg}: 31,3 \%$; placebo: 8,3\%) (18) (Tab. 2).

\section{Aktivním komparátorem kontrolovaná studie př́ípravku obsahující ertugliflozin v porovnání s glimepiridem jako přídatná léčba u pacientů nedostatečně kontrolovaných}

\section{metforminem v 52. týdnu (VERTIS SU)}

Studie vyhodnotila účinnost a bezpečnost 1× denně podaného ertugliflozinu 15 nebo 5 mg ve srovnání s glimepiridem (zahájení dávky $1 \mathrm{mg}$ a titrován do maxima 6-8 mg/den) $\checkmark 52$. týdnu u pacientů nedostatečně kompenzovaných metforminem. Primární cil, byl průkaz non-inferiority ve snížení $\mathrm{HbA}_{1 c}$. Ertugliflozin 15 mg byl non-inferiorní ke glimepiridu ve snížení $\mathrm{HbA}_{1 c}$ (ertugliflozin 15 mg vs. glimepirid $0,1[-0,0 ; 0,2] p<0,001)$, zatímco non-inferiorita nebyla prokázána pro ertugliflozin 5 mg $(0,2$ $[0,1 ; 0,3] \mathrm{p}=\mathrm{ns})(19)$

\section{Středně závažná porucha funkce ledvin studie (VERTIS RENAL)}

Účinnost ertugliflozinu byla také hodnocena v samostatné studii u pacientů se středně závažnou poruchou funkce ledvin (468 pacientů s eGFR $\geq 30 \mathrm{ml} / \mathrm{min} / 1,73 \mathrm{~m}^{2}$ až $<60 \mathrm{ml} / \mathrm{min} / 1,73 \mathrm{~m}^{2}$ ). Střední změny výchozích hodnot $\mathrm{HbA}$ (metodou nejmenších čtverců, $95 \%$ Cl) byly -0,26(-0,42; $-0,11)$ ve skupině s placebem, $-0,29(-0,44 ;-0,14)$ ve skupině s ertugliflozinem 5 mg a -0,41(-0,56;-0,27) ve skupině s ertugliflozinem 15 mg. Snížení $\mathrm{HbA}_{\mathrm{Ic}}$ $\checkmark$ ramenech s ertugliflozinem nebylo významně rozdílné od skupiny s placebem. Předem stanovená analýza glykemické účinnosti byla zkreslena současným použitím medikace, jejíž současné použití bylo zakázáno. V následné analýze s vyloučením subjektů, které použily zakázanou medikaci, bylo uživání ertugliflozinu 5 mg a 15 mg spojeno s na placebo korigovaným snižením $\mathrm{HbA}_{\mathrm{cc}}-0,14$ $(-0,36 ; 0,08)$ a $-0,33(-0,55 ;-0,11)(20)$.

V současné době probíhá také klinická studie, která je zaměřena na vyhodnocení kardiovaskulární bezpečnosti, která by mohla být ukončena koncem řijna 2019 (Graf 7).

\section{Hmotnost}

Stejně jako ostatní glifloziny je ertugliglozin účinný ve snižování hmotnosti, jak bylo prokázáno v randomizovaných studiích vzhledem ke ztrátě kalorií a zvýšené diuréze (21).

Po 26 týdnech léčby ertuglifozinem v monoterapii 5 a 15 mg osoby s DM2, které dosud nebyly farmakologicky léčeny, dosáhly signifikantního poklesu hmotnosti ve srovnání s placebem (ertugliflozin $5 \mathrm{mg}-1,76 \mathrm{~kg}$ ( $p<0,001$ ), ertugliflozin $15 \mathrm{mg}-2,16 \mathrm{~kg} \mathrm{p}<0,001)(12)$ 
FARMAKOLOGICKÝ PROFIL 【

ERTUGLIFLOZIN - INHIBITOR SGLT2

Tab. 2. Ertugliflozin: klinické shrnutí

\begin{tabular}{|c|c|c|c|}
\hline Výsledky ve 26. týdnu & $\begin{array}{c}\text { VERTIS SITA 2 } \\
\text { Ertugliflozin jako dopIněk } \\
\text { k metforminu a sitagliptinu }\end{array}$ & $\begin{array}{c}\text { VERTIS FACTORIAL } 2 \\
\text { Ertugliflozin plus sitagliptin } \\
\text { jako doplněk k metforminu }\end{array}$ & $\begin{array}{l}\text { VERTIS MET } 3 \\
\text { Ertugliflozin jako doplněk } \\
\text { k metforminu }\end{array}$ \\
\hline Snížení $\mathrm{HbA}_{1 \mathrm{c}}{ }^{\mathrm{a}, \mathrm{b}}$, \% & $\begin{array}{c}-0,8,-0,9 \\
\text { Výchozí 8,0, 8,1 }\end{array}$ & $\begin{array}{c}-1,5 \\
\text { Výchozí } 8,5,8,6\end{array}$ & $\begin{array}{c}-0,7,-0,9 \\
\text { Výchozí } 8,1\end{array}$ \\
\hline Snížení FPG ${ }^{a, b}$, mg/dl & $\begin{array}{c}-29,6,-33,0 \\
\text { Výchozí } 167,7,171,7\end{array}$ & $\begin{array}{c}-44,0,-48,7 \\
\text { Výchozí 183,8, } 177,2\end{array}$ & $\begin{array}{c}-27,0,-39,6 \\
\text { Výchozí } 167,6\end{array}$ \\
\hline Snížení tělesné hmotnostia, ${ }^{\mathrm{a}, \mathrm{b}}, \mathbf{k g}$ & $\begin{array}{c}-3,0,-3,4 \\
\text { Výchozí 86,6, } 87,6\end{array}$ & $\begin{array}{c}-2,5,-2,9 \\
\text { Výchozí } 87,5,89,5\end{array}$ & $\begin{array}{c}-2,9,-3,0 \\
\text { Výchozí } 84,9,85,3\end{array}$ \\
\hline $\begin{array}{l}\text { Snížení systolického } \\
\text { krevního tlaku }{ }^{\mathrm{a}, \mathrm{b}}, \mathrm{mmHg}\end{array}$ & $\begin{array}{c}-3,8,-4,8 \\
\text { Výchozí } 131,6,132,1 \\
\end{array}$ & $\begin{array}{c}-3,4,-3,7 \\
\text { Výchozí 129,1, 130,2 }\end{array}$ & $\begin{array}{c}-4,4,-5,2 \\
\text { Výchozí 130,2, 130,5 }\end{array}$ \\
\hline Profil nežádoucích příhod & Podobný mezi skupinami & Podobný mezi skupinami & Podobný mezi skupinami \\
\hline $\begin{array}{l}\text { Nežádoucí příhody } \\
\text { související s lékem }\end{array}$ & $\begin{array}{c}\text { Vyšší ve skupinách uživajících } \\
\text { ertugliflozin, převážně kvưli genitálním } \\
\text { mykotickým infekcím }\end{array}$ & \begin{tabular}{|c|} 
Vyšší ve skupinách užívajících \\
ertugliflozin, převážně kvưli genitálním \\
mykotickým infekcím
\end{tabular} & $\begin{array}{c}\text { Vyšší ve skupinách užívajících } \\
\text { ertugliflozin, převážně kvůli genitálním } \\
\text { mykotickým infekcím }\end{array}$ \\
\hline \multicolumn{4}{|c|}{ 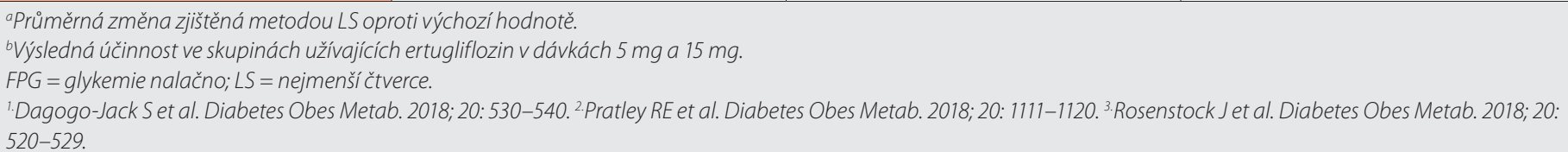 } \\
\hline
\end{tabular}

Pokles hmotnosti pokračoval i v extenzi do týdne 52, skupina léčená ertugliflozinem 5 mg snízila dále hmotnost -3,23 kg a ertugliflozinem 15 mg pak -3,38 kg ve srovnání s počátkem studie (DOV 45).

\section{Krevní tlak}

Ve třech 26týdenních, placebem kontrolovaných studiích ertugliflozin snižoval systolický krevní tlak.

Statisticky významná na placebo korigovaná snižení systolického tlaku se pohybovala od 2,9 mmHg do 3,7 mmHg pro ertugliflozin $5 \mathrm{mg}$ a od 1,7 $\mathrm{mmHg}$ do 4,5 $\mathrm{mmHg}$ pro ertugliflozin 15 mg. V 52týdenní, s aktivním komparátorem, glimepiridem, kontrolované studii, byla snížení systolického tlaku oproti výchozímu stavu 2,2 mmHg u ertugliflozinu $5 \mathrm{mg}$ a $3,8 \mathrm{mmHg}$ u ertugliflozinu 15 mg, zatímco u subjektů léčených glimepiridem došlo ke zvýšení výchozího systolického tlaku o 1 mmHg (8).

\section{Bezpečnost a snášenlivost}

Bezpečnostní profil ertugliflozinu je podobný tomu, jaký mají ostatní SGLT2i. Lze dle výsledků konstatovat, že byl ve studiích dobře tolerován, s většinou vedlejších účinků mírné nebo střední intenzity (22).

Ertugliflozin zvyšuje riziko mykotických infekcí genitálií. V klinických hodnoceních inhibitorů SGLT2 byl rozvoj mykotických infekcí genitálií pravděpodobnější u pacientů s mykotickými infekcemi genitálií v anamnéze a u neobřezaných mužů Pacienty je nutno sledovat a príslušně léčit (8).

\section{Infekce močového ústrojí}

Exkrece glukózy močí může být spojena se zvýšeným rizikem infekcí močového ústrojí. Incidence infekcí močového ústrojí se mezi skupinami s 5 mg a 15 mg ertugliflozinu (4,0 \% a 4,1 \%) a skupinou s placebem (3,9\%) významně nelišila. Většina př́padů byla mírná nebo středně závažná, nebyl hlášen žádný závažný prípad. Během léčby pyelonefritidy nebo urosepse se má zvážit dočasné vysazení ertugliflozinu.

\section{Hypotenze/deplece objemu}

Ertugliflozin vyvolává osmotickou diurézu, která může vést ke snížení intravaskulárního objemu.

Proto se po zahájení léčby prípravkem obsahujícím ertugliflozin může objevit symptomatická hypotenze, zejména u pacientů s poruchou funkce ledvin (eGFR nižší než $60 \mathrm{ml} / \mathrm{min} / 1,73 \mathrm{~m}^{2}$ nebo $\mathrm{CrCl}$ nižší než $60 \mathrm{ml} /$ min), starších pacientů ( $\geq 65$ let), pacientů léčených diuretiky nebo u pacientů léčených antihypertenzivy s hypotenzí v anamnéze. Před zahájením léčby prípravkem obsahujícím ertugliflozin má vyhodnotit a, pokud je to indikováno, napravit objemový status. Po zahájení léčby sledujte známky a príznaky.

Starší pacienti mohou být ve vyšší míře ohroženi deplecí objemu. Pacienti ve věku 65 let a starší léčení ertugliflozinem měli ve srovnání s mladšími pacienty vyšší incidenci nežádoucích účinků souvisejících s deplecí objemu. Předpokládá se, že ertugliflozin bude mít u starších pacientů s poruchou funkce ledvin sniženou účinnost.

\section{Diabetická ketoacidóza}

U pacientů léčených inhibitory sodíko-glukózového kotransportéru 2 (SGLT2) byly v klinických hodnoceních a po registraci hlášeny vzácné případy diabetické ketoacidózy, včetně život ohrožujících a smrtelných prípadů; takové prípady byly hlášeny i v klinických hodnoceních ertugliflozinu. $\vee$ řadě případů byly projevy stavu atypické s pouze středně závažným zvýšením hodnot glukózy v krvi, pod 14 mmol/l (250mg/dl). Není známo, zda je výskyt diabetické ketoacidózy při vyšších dávkách ertugliflozinu pravděpodobnějši (8).

\section{Amputace na dolních končetinách}

V probíhající klinické studii, ve které byl ertuglifozin přidán ke stávající léčbě u pacientů s diabetes mellitus typu 2 s kardiovaskulárním onemocněním v anamnéze, bylo pozorováno přibližně 1,2 až 1,6násobné zvýšení počtu prípadů amputací na dolních končetinách (především prstů). Zvýšení počtu prípadů amputací na dolních končetinách (především prstů) bylo též pozorováno v dlouhodobých klinických studiích jiného inhibitoru SGLT2. Protože vlastní mechanismus nebyl stanoven, rizikové faktory pro amputace, kromě obecných rizikových faktorů, nejsou známy. Dle doporučení v SPC před zahájením léčby ertugliflozinem bychom měli zvážit v anamnéze pacienta faktory, které mohou zvýšit riziko amputace. Jako preventivní opatření by měla být věnována pozornost pečlivému sledování pacientů s vyšším rizikem amputace, poradenství 


\section{FARMAKOLOGICKÝ PROFIL}

ERTUGLFLOZIN - INHIBITOR SGLT2

Graf 7. VERTIS CV: Design studie!,2

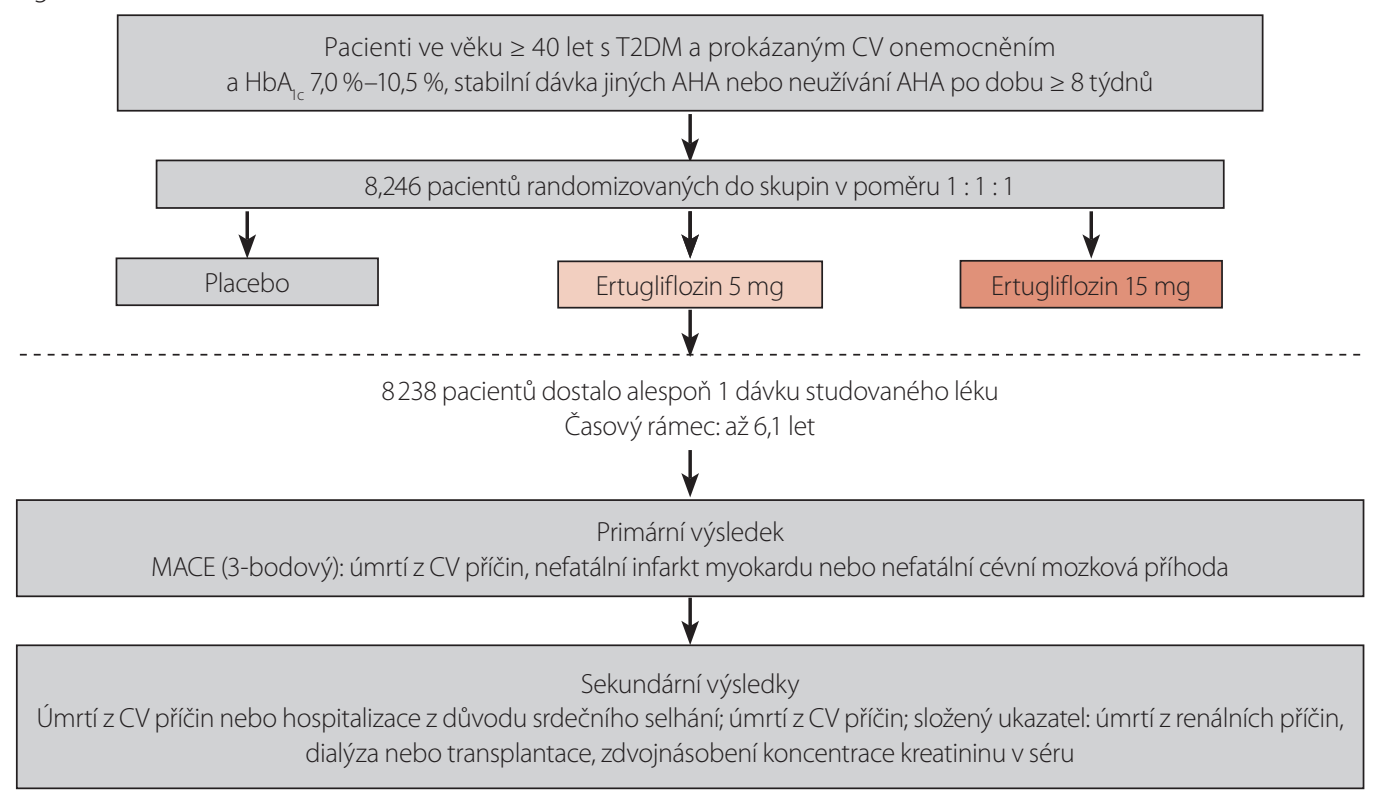

`V anamnéze ateroskleróza postihující koronární, cerebrální nebo periferní vaskulární systém.

T2DM = diabetes mellitus 2. typu; CV = kardiovaskulární; $A H A=$ antihyperglykemikum; MACE = závažnější nežádoucí kardiovaskulární príhoda.

1.https:/Clinicaltrials.gov/ct2/show/NCT01986881. November 9, 2017. 2.Cannon CP et al. Design and Baseline Characteristics of the eValuation of ERTugliflozin efflcacy and Safety CardioVascular Outcomes Trial (VERTIS-CV). Poster presented at: ACC 2018; March 10-12, 2018; Orlando, USA. Presentation 406-P.

o dưležitosti pravidelné preventivní péče o nohy a dodržování dostatečné hydratace. U pacientů, jimž se na dolních končetinách rozvinuly stavy předcházející amputaci, jako jsou vředy na kưži, infekce, osteomyelitida či gangréna, je třeba zvážit ukončení léčby ertugliflozinem (8).

\section{Zhoršení renálních funkcí}

Účinnost ertugliflozinu je závislá na funkci ledvin, přičemž u pacientů se středně závažnou poruchou funkce ledvin je snižena a u pacientů se závažnou poruchou funkce ledvin účinnost pravděpodobně není. Prípravek obsahující ertugliflozin se nemá nasazovat u pacientů s eGFR nižší než $60 \mathrm{ml} / \mathrm{min} / 1,73 \mathrm{~m}^{2}$ nebo $\mathrm{CrCl}$ nižší než $60 \mathrm{ml} / \mathrm{min}$. Př́pravek se má vysadit kvưli snížené účinnosti, pokud je eGFR setrvale nižší než 45 ml/ min/1,73 m² nebo $\mathrm{CrCl}$ setrvale nižší než $45 \mathrm{ml} / \mathrm{min}$.

Sledování renálních funkcí se doporučuje následovně:

- pred nasazením ertugliflozinu a pravidelně během léčby (viz bod 4.2).

- častěji u pacientů s eGFR nižší než $60 \mathrm{ml} /$ min/1,73 m² nebo $\mathrm{CrCl}$ nižší než $60 \mathrm{ml} / \mathrm{min}(8)$. Hypoglykemie při současném podávánís inzulinem a inzulinovými sekretagogy:

Ertugliflozin může riziko hypoglykemie zvyšovat, pokud se použíá v kombinaci s inzulinem a/nebo inzulinovým sekretagogem, o kterých je známo, že způsobuji hypoglykemii. Proto může být k minimalizaci rizika hypoglykemie potřebná nižší dávka inzulinu nebo inzulinového sekretagoga, pokud se použivají v kombinaci s ertugliflozinem.

\section{Praktické aspekty léčby}

Prípravky obsahující ertugliflozin 5 a 15 mg jsou indikovány k léčbě dospělých ve věku 18 let a starších s diabetem mellitus typu 2 jako doplňková léčba k dietním opatřením a tělesné aktivitě ke zlepšení kontroly glykemie:

- jako monoterapie u pacientů, u kterých se metformin nepovažuje za vhodný kvưli intoleranci nebo kontraindikacím

- a jako prídatná léčba k dalším antidiabetikům. Doporučená zahajovací dávka ertugliflozinu je 5 mg jednou denně. U pacientů snášejících 5 mg ertug liflozinu jednou denně lze dávku zvýšit na 15 mg jednou denně, pokud je potřebná další kontrola glykemie.

Pokud se ertugliflozin používá v kombinaci s inzulinem nebo inzulinovým sekretagogem, může být ke snížení rizika hypoglykemie potřebná nižší dávka inzulinu nebo inzulinového sekretagoga.

U pacientů s deplecí objemu se před nasazením ertugliflozinu doporučuje náprava tohoto stavu.

Pokud dojde k vynechání dávky, má ji pacient užít, jakmile si vzpomene. Pacienti nemají užívat dvě dávky prípravku obsahující ertugliflozin ve stejný den.

U pacientů s mírnou nebo středně závažnou poruchou funkce jater není nutná úprava dávky ertugliflozinu. U pacientů se závažnou poruchou funkce jater nebyl ertugliflozin hodnocen a jeho použití u těchto pacientů se nedoporučuje.

Prípravky s obsahem ertugliflozinu se nemají používat k léčbě pacientů s diabetem mellitus typu 1.

Bezpečnost a účinnost ertugliflozinu u dětí mladších 18 let nebyla stanovena. Nejsou dostupné žádné údaje.

Kontraindikací je hypersenzitivita na léčivou látku nebo na kteroukoli pomocnou látku uvedenou $v$ SPC.

\section{Závěr}

Ertugliflozin prezentuje další účinný, bezpečný a dobře snášený inhibitor SGLT2 pro léčbu diabetes mellitus 2. typu. Jeho na inzulinu nezávislý mechanismus je účinný na snížení $\mathrm{HbA}_{1 c^{\prime}}$ krevního tlaku a hmotnosti jak v monoterapii, tak v kombinacích s dalšími antidiabetiky.

Zatím nemáme studie, které by prímo srovnávaly ertugliflozin s dalšími již použivanými glifloziny. Zajímavé jsou výsledky klinických studií, kdy byl použit v kombinaci se sitagliptinem s nesporným účinkem na kompenzaci. V současné době probíhá také klinická studie, která je zaměřená na vyhodnocení kardiovaskulární bezpečnosti, která je nyní jeden z hlavních požadavků na antidiabetickou léčbu. 
FARMAKOLOGICKÝ PROFIL I

ERTUGLIFLOZIN - INHIBITOR SGLT2

\section{LITERATURA}

1. Doporučený postup péče o diabetes mellitus 2. typu, Česká diabetologická společnost J. Škrha, T. Pelikánová, M. Kvapil, dostupná z www.diab.cz

2. Pajor AM, Wright EM. Cloning and functional expression of a mammalian $\mathrm{Na}+$ /nucleoside cotransporter. A member of the SGLT family. J Biol Chem. 1992; 267(6): 3557-3560. 3. Wang XX, Levi J, Luo Y, et al. SGLT2 protein expression is increased in human diabetic nephropathy: SGLT2 protein inhibition decreases renal lipid accumulation, inflammation and the development of nephropathy in diabetic mice. J Biol Chem. 2017; 292(13): 5335-5348.

4. Mascitti V, Maurer TS, Robinson RP, et al. Discovery of a clinical candidate from the structurally unique dioxa-bicyclo[3. 2. 1] octane class of sodium-dependent glucose cotransporter 2 inhibitors. J Med Chem. 2011; 54(8): 2952-2960.

5. Dash RP, Babu RJ, Srinivas NR. Comparative pharmacokinetics of three SGLT-2 inhibitors sergliflozin, remogliflozin and ertugliflozin: an overview. Xenobiotica. 2016: 1-12.

6. Kalgutkar AS, Tugnait M, Zhu T, et al. Preclinical species and human disposition of PF-04971729, a selective inhibitor of the sodium-dependent glucose cotransporter 2 and clinical candidate for the treatment of type 2 diabetes mellitus. Drug Metab Dispos. 2011; 39(9): 1609-1619.

7. Miao Z, Nucci G, Amin N, et al. Pharmacokinetics, metabolism, and excretion of the antidiabetic agent ertugliflozin (PF-04971729) in healthy male subjects. Drug Metab Dispos. 2013:41(2):445-456.

8. SPC Steglatro.http://www.ema.europa.eu/docs/cs_CZ/ document_library

9. Kumar V, Sahasrabudhe V, Matschke K, et al. Lack of a pharmacokinetic interaction between ertugliflozin and sitagliptin or metformin in healthy subjects. Poster presented at: ASCPT
2016 Annual Meeting of the American Society for Clinical Pharmacology and Therapeutics; March 12; 2016; San Diego, CA. 10. Sahasrabudhe V, Terra SG, Fountaine RJ, et al. The effect of renal impairment on the pharmacokinetics and pharmacodynamics of ertugliflozin in subjects with type 2 diabetes mellitus. Poster presented at: EASD 2015 51st European Association for the Study of Diabetes; September 14; 2015; Stockholm, Sweden. 11. Amin NB, Wang X, Jain SM, Lee DS, Nucci G, Rusnak JM. Dose-ranging efficacy and safety study of ertugliflozin, a sodium-glucose co-transporter 2 inhibitor, in patients with type 2 diabetes on a background of metformin. Diabetes Obes Metab. 2015:17(6):591-598

12. Terra SG, Focht K, Davies M, et al. Phase III, efficacy and safety study of ertugliflozin monotherapy in people with type 2 diabetes mellitus inadequately controlled with diet and exercise alone. Diabetes Obes Metab. 2017; 19(5): 721-728. 13. Rosenstock J, Frias J, Pall D, et al. Effect of ertugliflozin on glycemic control, body weight, blood pressure (BP), and bone mineral density (BMD) in T2DM inadequately controlled with metformin monotherapy: VERTIS MET Trial. Poster presented at: ADA 2017; June 8; 2017; San Diego, CA.

14. Pratley R, Eldor R, Golm G, et al. Safety and efficacy of ertugliflozin plus sitagliptin versus either treatment alone in subjects with type 2 diabetes inadequately controlled with metformin: the VERTIS FACTORIAL trial. Poster presented at: EASD 2016 52nd European Association for the Study of Diabetes; September 15; 2016; Munich, Germany.

15. Pratley R, Raji A, Eldor R, et al. Safety and efficacy of ertugliflozin plus sitagliptin vs. either treatment alone after 52 weeks in subjects with T2DM inadequately controlled on metformin: VERTIS FACTORIAL trial extension. Oral presentation at: ADA 2017; June 9; 2017; San Diego, CA.
16. Lauring B, Eldor R, Liu J, et al. Efficacy and safety of ertugliflozin in subjects with type 2 diabetes mellitus inadequately controlled on the dual combination of metformin and sitagliptin: the VERTIS SITA2 trial. Poster presented at: EASD 2016 52nd European Association for the Study of Diabetes September 15; 2016; Munich, Germany.

17. Liu J, Eldor R, Dagogo-Jack S, et al. Safety and efficacy of ertugliflozin after 52 weeks in subjects with T2DM inadequately controlled on metformin and sitagliptin: results from the extension phase of the VERTIS SITA2 Trial. Oral presentation at: ADA 2017; June 9; 2017; San Diego, CA.

18. Lauring B, Miller SS, Krumins T, et al. Safety and efficacy of ertugliflozin in combination with sitagliptin in subjects with T2DM inadequately controlled on diet and exercise: the VERTIS SITA Trial. Poster presented at: ADA 2017; June 8; 2017; San Diego, CA.

19. Hollander P, Liu J, Hill J, et al. Safety and efficacy of ertugliflozin compared to glimepiride in patients with type 2 diabetes inadequately controlled on metformin: the VERTIS SU trial. Poster presentation at: EASD 2017; Lisbon, Portugal.

20. Grunberger G, Camp S, Johnson J, Huyck S, Terra SG, Mancuso JP, et al. Ertugliflozin in patients with stage 3 chronic kidney disease and type 2 diabetes mellitus: the VERTIS RENAL randomized study. Diabetes Ther 2018.

21. Rajeev SP, Cuthbertson DJ, Wilding JP. Energy balance and metabolic changes with sodium-glucose co-transporter 2 inhibition. Diabetes Obes Metab. 2016; 18(2): 125-134 22. Inzucchi SE, Zinman B, Wanner C, et al. SGLT-2 inhibitors and cardiovascular risk: proposed pathways and review of ongoing outcome trials. Diabetes Vasc Dis Res. 2015; 12(2): 90-100. 